\title{
Factors Influencing Research Productivity of Private Higher Education Institutions Lecturers in Kopertis Region XII Maluku and North Maluku
}

\author{
Jusuf N. Anamofa ${ }^{1}$, Ricardo F. Nanuru ${ }^{2}$, Johanis Wairata ${ }^{2}$, Suhardi Suhardi ${ }^{3}$, Iriyani Abd. Kadir ${ }^{3}$, \\ Vanessa Lekahena ${ }^{4}$, Tekat Dwi Cahyono ${ }^{5}$, Sharlota Y. Purimahua ${ }^{6}$, Ebedly Lewerissa ${ }^{2}$, Broery D.P. \\ Tjaja $^{2}$, Henky H. Hetharia ${ }^{6}$, Khaeril Khaeril ${ }^{7}$, Salomi J. Hehanussa ${ }^{6}$, Amiruddin Hi. Muhammad ${ }^{3}$, \\ Dellen N. Matulessy ${ }^{8}$, Peinina I. Nindatu ${ }^{9}$, Maya Laisila ${ }^{6}$, Astuti Tuharea ${ }^{10}$, Amelia Tahitu ${ }^{6}$, Jolyne $^{2}$ \\ M. Parera ${ }^{6}$, Maryani Yusuf ${ }^{11}$, Windy Wonmally ${ }^{1}$, Marlen Sahureka ${ }^{1}$, Aveanty Miagina ${ }^{2}$, Radios \\ Simanjuntak $^{2}$, Sefnat A. Hontong ${ }^{2}$, Nusye Lewaherilla ${ }^{6}$, Paulus Rikumahu $^{6}$, Johana Tandisala $^{8}$, \\ Richard Djiko ${ }^{8}$, Marcus Latupapua ${ }^{8}$, Pipit A. Susanti ${ }^{12}$ \\ ${ }^{1}$ Gotong Royong College of Teacher Education and Education Sciences, Masohi, Indonesia \\ ${ }^{2}$ Halmahera University, Tobelo, Indonesia \\ ${ }^{3}$ Nuku University, Tidore, Indonesia \\ ${ }^{4}$ Muhammadiyah University of North Maluku, Ternate, Indonesia \\ ${ }^{5}$ Darussalam University, Ambon, Indonesia \\ ${ }^{6}$ Christian University of Indonesia Maluku, Ambon, Indonesia \\ ${ }^{7}$ Rutu Nusa College of Economic Management, Ambon, Indonesia \\ ${ }^{8}$ Halmahera Peace Polytechnic, Tobelo, Indonesia \\ ${ }^{9}$ Banau Agriculture and Entrepreneurship College, Jailolo, Indonesia \\ ${ }^{10}$ Maluku Husada College of Health, Kairatu, Indonesia \\ ${ }^{11}$ Bumi Hijrah University, Tidore, Indonesia \\ ${ }^{12}$ Kie Raha College of Teacher Education and Education Sciences, Ternate, Indonesia \\ anamofaj@gmail.com,ricardonanuru632@gmail.com
}

Keywords: $\quad$ research productivity, private higher education institutions, lecturers, Kopertis Region XII

Abstract: A researcher is said to be productive after publishing their findings. The analysis of the Science and Technology Index portal, called SINTA, shows the productivity of researches of private higher education institutions lecturers in Kopertis Region XII Maluku and North Maluku is still very low. The ranking of private higher education institutions in Kopertis Region XII compared with other universities in Indonesia further strengthens the opinion. This research aimed to determine the factors influencing the research productivity of private higher education institutions lecturers in Kopertis Region XII. The method used was an online survey on 155 samples of lecturers in Maluku and North Maluku. The data obtained were analyzed statistically descriptive. The results showed that research productivity is influenced by individual and institutional factors. Individually, the biggest driving factor is the perception of the function and benefits of research for human life, while the smallest one is the desires to be famous and financial benefits. The biggest inhibiting factor is the limited cost of research and publication, while the smallest is the motivation to research and publish. Institutionally, library facilities are deemed inadequate, thus contributing less to the increase of research productivity.

\section{INTRODUCTION}

Research activities and research productivity are two different things but closely related issues. The productivity of the research will exist if the research activity is carried out. Research activity means conducting research, collecting and analyzing data. Research productivity means writing and publishing research articles in professional scientific journals, as chapters in books, or presenting papers in scientific conferences for publication in proceedings (Iqbal, 2011). Results of a research should be 
published so that the findings and ideas of researchers can be known, recognized, and acknowledged by peoples and peers in the same field. Scientific publication is a publication system based on peer reviewed by experts in the same field of science in order to obtain a high level of objectivity. Scientific publication is also a key requirement for the promotion of an academic functional position of a lecturer (Lukman et al., 2017). Related to scientific publications, the Ministry of Research, Technology and Higher Education of the Republic of Indonesia (Kemenristekdikti) has constructed and developed the Science and Technology Index portal, called SINTA, which provides comprehensive information on scientific publications of researchers in Indonesia (Ristekdikti, 2017).

Kopertis Region XII Maluku and North Maluku has 45 private higher education institutions and 1,407 lecturers (Kemenristekdikti, 2018). The search for the SINTA portal shows that only 78 lecturers $(6 \%)$ of the total lecturers are registered as verified authors. The number is only $0.10 \%$ compared to the total verified authors on SINTA portal which is 78,314 as of $30^{\text {th }}$ of January 2018. The number of Scopus indexed publications is 11 or $0.02 \%$ of the total Scopus indexed publications on SINTA portal which is 59,132 , consisting of 10 journal articles $(0.03 \%$ of 39,630$)$ and 1 conference paper $(0.01 \%$ of $16,533)$; however, there is no publication of book chapter. The number of publications uploaded to Google Scholar is 931 ( $0.11 \%$ of 884,153$)$.

The date indicate that: a) Only a small number of lecturers in Kopertis Region XII is registered as verified author on SINTA portal; b) The productivity of research of lecturers in Kopertis Region XII is still very little. This is inversely proportional to the expectation that lecturers can conduct research and publication as one of the main tasks. Other data show that only 2 institutions in Kopertis Region XII are in $3^{\text {rd }}$ rank cluster of Indonesian Higher Education Institutions. Those two institutions are located in North Maluku Province (Kopertis12, 2017).

This research aimed to determine the factors influencing the research productivity of lecturers in Kopertis Region XII Maluku and North Maluku. Private higher education institutions lecturers are selected as population because the data on SINTA portal shows very significant differences in terms of research productivity between lecturers of state and private institutions. Kopertis Region XII became the research locus as it is the working area of the researchers.
The findings of previous studies show several factors related to research activity and productivity, which are: a) motivation to research and write (Zain et al., 2011); b) Psychological character, work culture, age, productivity of work environment, and institutional prestige (Fox, 1983); c) Individual and institutional factors (Fawzi and Al-Hattami, 2017); d) Insufficient research funding, university environments hampering research development, procurement regulations limiting the participation of universities in government sponsored research (Yanuar, Prasetiamarti and Ruhanawati, 2016).

\section{METHODS}

This research used survey method conducted for lecturers in Kopertis Region XII in JanuaryFebruary 2018. The number of respondents of this research was 155 people, who had met the targeted sample of at least $10 \%$ of the total population which was 1.407. The number of samples was representative because the analytical technique used was descriptive statistics to obtain a more regular and easy data description related to research activities and productivity based on: a) individual factors including perceptions, technical abilities, driving factors, inhibiting factors; and b) institutional factors. The instrument for collecting data is an online questionnaire that contains questions based on the indicators of previous research findings.

\section{FINDING AND DISCUSSION}

\subsection{Profile of Respondents}

In terms of gender, there are 88 male $(57 \%)$ and 67 female $(43 \%)$ respondents. Based on age, there are 83 respondents with age range of 24-35 years old (54\%), 49 people whose ages are 36-45 years old (32\%), 15 people in $46-55$ years old $(10 \%)$ and 8 people are over 56 years old $(5 \%)$. Based on employment status, there are 28 lecturers with Civil Servants status employed in private institutions (18\%) and 127 foundation lecturers (82\%). There are 59 respondents from Maluku Province (38\%) and 96 from North Maluku Province (62\%). According to the level of education, there are 6 people from Bachelor Degree (4\%), 135 from Master (87\%), and 14 from Doctoral degree (9\%). Based on the field of science, there are 52 people 
from physical sciences and life sciences (34\%), 78 respondents from social sciences, arts, and humanities (50\%), 5 from formal sciences (mathematics, statistics, and computers) (3\%), and 20 people from teachers training and education (20\%). From the lecturers' functional position, there are 52 expert assistants (34\%), 42 persons are lector (27\%), 11 are head lector (7\%), and none are professors $(0 \%)$, and there are 50 people who do not have a functional position (32\%). Total of $74(48 \%)$ of respondents are structural officials in their institutions, while $81(52 \%)$ are not structural officials. Based on the status as a verified author on SINTA portal, there are 27 people registered as verified authors (17\%) and 128 unregistered (83\%). Based on Google Scholar registration, 49 people already have Google Scholar accounts $(32 \%)$, and 106 others do not have the account (68\%).

The profile shows some things that should be paid attention, that: a) most of them are young lecturers with age range between 24-35 years old; b) there are still some lecturers graduating from Bachelor Degree, while most of the lecturers graduated from Master Degree; c) there are still lecturers who do not have academic functional positions consisting of $44(88 \%)$ Master graduates and $6(12 \%)$ Bachelors, most are still expert assistants; d) there are still many lecturers who have not registered as verified author on SINTA portal; e) there are still many lecturers who do not have Google Scholar account yet.

\subsection{Factors Influencing Research Productivity}

Table 1: Individual driving factors.

\begin{tabular}{|l|c|c|}
\hline \multicolumn{1}{|c|}{ Item } & Mean & Std.Dev. \\
\hline Research as the main task & 4.73 & .446 \\
\hline $\begin{array}{l}\text { Research provides a } \\
\text { solution }\end{array}$ & 4.55 & .536 \\
\hline $\begin{array}{l}\text { Research results should be } \\
\text { turned into articles / papers }\end{array}$ & 4.54 & .573 \\
\hline $\begin{array}{l}\text { Every written article / } \\
\text { paper should be published }\end{array}$ & 4.45 & .646 \\
\hline Research for new findings & 4.37 & .560 \\
\hline $\begin{array}{l}\text { Research should be done at } \\
\text { least once a year }\end{array}$ & 4.33 & .646 \\
\hline $\begin{array}{l}\text { Feeling confident for the } \\
\text { research in the area of } \\
\text { expertise }\end{array}$ & 4.29 & .581 \\
\hline $\begin{array}{l}\text { Feeling confident for } \\
\text { collaboration }\end{array}$ & 4.21 & .603 \\
\hline $\begin{array}{l}\text { Being able to write good } \\
\text { articles / papers }\end{array}$ & 4.21 & .592 \\
\hline Feeling confident to write & 4.16 & .650 \\
\hline
\end{tabular}

\begin{tabular}{|l|c|c|}
\hline articles / papers & & \\
\hline $\begin{array}{l}\text { Publication as a scientific } \\
\text { communication }\end{array}$ & 4.05 & .759 \\
\hline $\begin{array}{l}\text { Understanding the criteria } \\
\text { of publication }\end{array}$ & 3.90 & .779 \\
\hline $\begin{array}{l}\text { Research for lecturer } \\
\text { functional promotion }\end{array}$ & 3.47 & 1.015 \\
\hline $\begin{array}{l}\text { Publication for lecturer } \\
\text { functional promotion }\end{array}$ & 3.35 & .910 \\
\hline $\begin{array}{l}\text { Publications to be } \\
\text { acknowledged by the public }\end{array}$ & 3.28 & .972 \\
\hline Research for financial gain & 2.81 & .994 \\
\hline Research for famous & 2.48 & .878 \\
\hline
\end{tabular}

Table 2: Individual inhibiting factors.

\begin{tabular}{|l|c|c|}
\hline \multicolumn{1}{|c|}{ Item } & Mean & Std.Dev. \\
\hline Lack of research costs & 3.31 & 1.042 \\
\hline Lack of publication costs & 3.19 & .979 \\
\hline $\begin{array}{l}\text { Lack of information about } \\
\text { reputation } \\
\text { journals/conferences }\end{array}$ & 3.12 & .993 \\
\hline Lack of researcher network & 3.03 & 1.041 \\
\hline Lack of research mentoring & 2.88 & 1.075 \\
\hline Great teaching load & 2.81 & .947 \\
\hline Lack of good references & 2.71 & 1.057 \\
\hline Administrative task & 2.68 & 1.025 \\
\hline $\begin{array}{l}\text { Lack of research data } \\
\text { resources }\end{array}$ & 2.54 & .955 \\
\hline $\begin{array}{l}\text { Submitted articles have } \\
\text { been rejected }\end{array}$ & 2.52 & .767 \\
\hline $\begin{array}{l}\text { Being busy taking care of } \\
\text { the family }\end{array}$ & 2.23 & .670 \\
\hline $\begin{array}{l}\text { Lack of mastery of } \\
\text { research procedures and } \\
\text { techniques }\end{array}$ & 2.23 & .804 \\
\hline Age factor & 2.04 & .711 \\
\hline $\begin{array}{l}\text { Feeling pressure while } \\
\text { writing }\end{array}$ & 2.01 & .806 \\
\hline $\begin{array}{l}\text { Lack of research } \\
\text { motivation }\end{array}$ & 1.91 & .759 \\
\hline
\end{tabular}

Table 3: Institutional factors.

\begin{tabular}{|l|c|c|}
\hline \multicolumn{1}{|c|}{ Item } & Mean & Std.Dev. \\
\hline $\begin{array}{l}\text { Vision and mission of } \\
\text { Universities prioritize } \\
\text { research }\end{array}$ & 4.02 & .810 \\
\hline $\begin{array}{l}\text { The university encourages } \\
\text { lecturers to conduct } \\
\text { research }\end{array}$ & 3.93 & .774 \\
\hline $\begin{array}{l}\text { The University research } \\
\text { institute assists in research }\end{array}$ & 3.76 & .954 \\
\hline $\begin{array}{l}\text { The University research } \\
\text { institute assists with the } \\
\text { scientific publications }\end{array}$ & 3.44 & .944 \\
\hline $\begin{array}{l}\text { The University helps obtain } \\
\text { research donors }\end{array}$ & 3.41 & 1.011 \\
\hline Good Cultural Research in & 3.16 & 1.010 \\
\hline
\end{tabular}




\begin{tabular}{|l|c|c|}
\hline the Private Universities & & \\
\hline $\begin{array}{l}\text { Providing a decent } \\
\text { appreciation for scientific } \\
\text { publications }\end{array}$ & 3.12 & .980 \\
\hline Adequate Library & 2.91 & 1.071 \\
\hline
\end{tabular}

The findings of the research indicate that the respondent's approval of the driving factor is greater than the institutional and inhibiting factor of research productivity. In addition, the lack of research motivation gets the smallest points of all inhibiting factors. However, the recognition is not worth the practical step for productive research. The perception of research conducted at least once a year is confirmed by the fact that $82(53 \%)$ of respondents conduct research each year. $77(50 \%)$ respondents were in the process of conducting research at the time of the survey, $43(28 \%)$ respondents did their last research in less than a year, and $35(23 \%)$ respondents had not conducted any research for over a year. This is in line with the findings of Santo et.al and Jung (Fawzi and AlHattami, 2017) who stated that lecturers recognize the importance of research but do not implement it in practical steps. This inability is closely related to inhibiting factors.

In accordance with the research findings, the lack of research and publication costs is considered the first factor inhibiting research productivity. This factor has become a common problem in Indonesia (Brodjonegoro and Greene, 2014; Yanuar, Prasetiamarti and Ruhanawati, 2016; Saroh, 2017). In relation to that, several sources of research financing are available but not sufficient. For institutional internal financing, 78 (50\%) respondents stated that their institution provided research funding, $39(25 \%)$ stated that no institutional funding was available, $38(25 \%)$ said they did not know. The government has provided research funding for lecturers through the Research and Community Service Information System (Simlitabmas) from the Kemenristekdikti, but up to the survey, 68 (44\%) lecturers have never submitted research proposals through the system.

The next inhibiting factor is the lack of information about reputable journals or conferences. The research findings show that $110(71 \%)$ of respondents have published articles in national scientific journals that are not accredited, 52 people (34\%) have published articles in accredited national scientific journals, 26 respondents $(17 \%)$ have published articles in International journals, 13 (8\%) have published articles in reputable international journals, and 29 people (19\%) have never published articles in any journal. $56(36 \%)$ of respondents have presented their papers at national conferences, 20 (13\%) have presented their papers at international conferences, and 39 (25\%) have written book chapters. The average of unaccredited national journals is the institution-owned journals managed for the purposes of functional promotion of lecturers. Percentages of accredited or higher than national journals are decreasing. One of the reasons is lack of information. Information regarding to this is considered important because there are many journals and conference predators who only want profit from scientists. The basic and complete information related to predators journals and conferences must be owned by researchers so that they do not make mistakes in publishing their research results, especially with publicity demands of prestigious indexation. Predator publishers hurt scientists, science, and science communications (Beall, 2016).

Another significant inhibitory factor is the lack of connection among researchers. The research findings show that $97(63 \%)$ of respondents have collaborated in research with lecturers in private universities, and 47 (30\%) of respondents have collaborated with parties outside private universities. It means that the collaboration between different institutional researchers is still in a small percentage. No involvement of a researcher in a network of researchers as well as interdisciplinary outside the institution can influence the productivity of their research (Ghazali and Abdullah, 2002; Zhang, 2014).

From the institutional side, adequate library facilitation becomes a factor that is considered sufficient to inhibit the productivity of research so that it is given the lowest recognition. One of the facilities that can be utilized by researchers in the library is a scientific journal, ranging from reputable national to international journals. 17 (11\%) of respondents stated that their institution subscribed to reputable international journals, and the other 138 (89\%) remained unsubscribed. Libraries with good facilities will encourage many things related to research, such as, being able to help higher education institutions develop research resources to become reliable researchers, able to help researchers prepare for good research proposals and win the financing and research contracts, able to introduce new scientific communication models among researchers, and so on ((Rin) and (Rluk), 2011). 


\section{CONCLUSIONS}

The results show that research productivity is influenced by individual and institutional factors. Individually there are both driving and inhibiting factors. The biggest driving factor is the perception of the function and benefits of research for human life. The smallest driving factor is the desire to become famous and financial gain. The biggest inhibiting factor is the lack of research and publication costs. The smallest inhibiting factor is related to research motivation. Institutionally, what is considered less to contribute to improving research productivity is library facilities.

This research needs to be developed again to obtain a more comprehensive description related to the research problem. The Kopertis Region XII needs to encourage lecturers to have Google Scholar accounts and register themselves as verified authors on SINTA portal because the research findings indicate that many publications have not been indexed in both Google Scholar and SINTA as those researchers have not been registered. In addition, policies related to research financing and publications need to be re-examined.

\section{REFERENCES}

(Rin), R. I. N. and (Rluk) (2011) The value of libraries for research and libraries: $a$ RIN and RLUK report.

Beall, J. (2016) 'Essential Information about Predatory Publishers and Journals', International Higher Education, (86), p. 2. doi: 10.6017/ihe.2016.86.9358.

Brodjonegoro, S. and Greene, M. (2014) 'Creating an Indonesian Science Fund', Jakarta: Indonesian Academy of Sciences. Available at: https://www.aipi.or.id/admin/assets/pdf/publication/in donesiansciencefundpdf_4Q91Q.pdf.

Fawzi, H. and Al-Hattami, A. (2017) 'Faculty Production of Research Papers: Challenges and Recommendations', International Journal of Humanities and Social Science, 7(2), pp. 221-228. Available at: http://www.ijhssnet.com/journals/Vol_7_No_2_Febru ary_2017/29.pdf.

Fox, M. F. (1983) 'Publication Productivity among Scientists: A Critical Review', Social Studies of Sciences, 13(2), pp. 285-305. Available at: https://scholar.google.com/.

Ghazali, S. S. and Abdullah, N. (2002) A Study on Research Productivity Amongst UiTM Academicians: Factors and Implications. Available at: https://s3.amazonaws.com/academia.edu.documents/3 5148648/LP_SITI_SALINA_GHAZALI_02_24.pdf? AWSAccessKeyId=AKIAIWOWYYGZ2Y $\overline{2}$-ULL3A\&
Expires $=1513150488 \&$ Signature $=$ h08gM3V\%2BqfId 0Wfi87Rmv8w6bCU\%3D\&response-content-

disposition=attachment $\% 3 \mathrm{~B}$ filename\%3DA_STUDY_ON_RE.

Iqbal, M. Z. (2011) 'Factors Related to Low Research Productivity at Higher Education Level', Asian Social Science, 7(2), pp. 188-193. Available at: http://www.ccsenet.org/journal/index.php/ass/article/d ownload/9138/6697.

Kemenristekdikti (2018) SRV4 PDDIKTI: Pangkalan Data Pendidikan Tinggi. Available at: http://forlap.dikti.go.id/ (Accessed: 31 January 2018).

Kopertis12 (2017) Peringkat Perguruan Tinggi Indonesia Tahun 2017 Provinsi Maluku dan Maluku Utara. Available

http://www.kopertis12.or.id/2017/11/17/peringkatperguruan-tinggi-indonesia-tahun-2017-provinsimaluku-dan-maluku-utara.html (Accessed: 27 January 2018).

Lukman et al. (2017) Pedoman Publikasi Ilmiah. Jakarta: Direktorat Pengelolaan Kekayaan Intelektual Direktorat Jenderal Penguatan Riset dan Pengembangan Kementerian Riset, Teknologi, dan Pendidikan Tinggi.

Ristekdikti (2017) SINTA - Science and Technology Index. Available at: http://sinta2.ristekdikti.go.id/ (Accessed: 14 December 2017).

Saroh, M. (2017) Dana Riset Indonesia Paling Rendah di Asia Tenggara, Tirto.ID. Available at: https://tirto.id/dana-riset- indonesia-paling- rendah-diasia-tenggara- chUP (Accessed: 4 February 2018).

Yanuar, N., Prasetiamarti, B. and Ruhanawati, S. (2016) 'Mengatasi Hambatan Penelitian di Universitas', pp. 1-22. Available at: http://www.ksiindonesia.org/files/1464160545\$1\$DYOBW\$.pdf.

Zain, S. M. et al. (2011) 'Motivation for research and publication: Experience as a researcher and an academic', Procedia - Social and Behavioral Sciences. Elsevier B.V., 18, pp. 213-219. doi: 10.1016/j.sbspro.2011.05.030.

Zhang, X. Y. (2014) 'Factors that Motivate Academic Staff to Conduct Research in Chinese Universities', Factors that Motivate Academic Staff to Conduct Research and Influence Research Productivity in Chinese Project 211 Universities, (October), pp. 1238. Available at: http://www.wbiconpro.com/china_con2011.htm. 